\title{
The Influence Of Firm's Fair Value System On Earnings Quality Under IFRS
}

\author{
Chang Seop Rhee, Sejong University, South Korea \\ Eun Sil Choi, Korea University, South Korea \\ Ji Yeon Ryu, Korea University, South Korea
}

\begin{abstract}
This paper analyzes the influence of firms'fair value system on earnings quality under IFRS. Korean firms are required to adopt IFRS in 2011. IFRS adoption was expected to increase value relevance of book value of equity and benefit information users' decision making. However, prior Korean studies report that value relevance of book value of equity is indifferent between under K-GAAP and IFRS. We consider that the indifference in value relevance of book value of equity after IFRS adoption is due to different level of fair value system among firms. We investigate whether the different level of fair value system among firms lead to the difference in earnings quality. Furthermore, we examine how each firm's fair value system affect earnings quality under IFRS.

This study finds following results. First, firms with weak fair value system smooth income more frequently. Second, firms with weak fair value system experience small amount of positive profit and slight increase in net income compared to prior period more frequently. Third, firms with weak fair value system make less timely loss recognition. Lastly, book value of equity and goodwill has low relative value relevance for weak fair value systemic firms, while both book value of equity and goodwill have incremental value relevance for firms with strong fair value evaluation system.
\end{abstract}

Keywords: IFRS; Fair Value System; Earnings Quality; Goodwill

\section{INTRODUCTION}

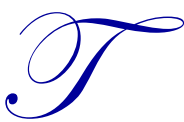

his paper examines whether fair value system under IFRS is associated with earnings quality, using Korean firm-year observations. Korean listed companies adopted IFRS in 2011 mandatorily. The IFRS adoption in Korea was expected to increase value relevance of book value of equity and benefit information users' decision making (Choi \& Rhee, 2015; Rhee, Yoo, \& Cha, 2016). Despite the expectation, prior Korean studies report that value relevance of book value of equity is indifferent between under K-GAAP, accounting standards prior to IFRS adoption, and IFRS (Choi, Kim, \& Choi, 2011; Choi, 2013). We expect the indifference in value relevance of book value of equity after IFRS adoption is due to different level of fair value system among firms. Before IFRS adoption, firms were unaccustomed to evaluating assets and liabilities in fair value. After adopting IFRS, the level of fair value system determines the effectiveness of accounting information, because each firm could practice fair value system differently. In other words, if a firm properly interprets and practices extended fair value evaluation due to IFRS adoption, information it provides would reflect firm's economic substance, which will benefit information users to make reasonable decisions. However, if a firm chooses to practice IFRS fair value evaluation as a method of income smoothing or meet-or-beat target earning, information effectiveness would decrease under IFRS.

In this study, we investigate whether the different level of fair value system among firms lead to the difference in earnings quality. Furthermore, we examine how each firm's fair value system affect earnings quality under IFRS. We measure the level of fair value evaluation system by goodwill accounting method for following reasons. First, managers can behave opportunistic in calculating fair value of goodwill. Calculation of goodwill value involves subjective estimations, such as projected cash generating unit, which is open to possible manipulation. In addition, characteristic of goodwill account is that it is unlikely to be reversed in the future, which makes vulnerable for management manipulation. In fact, goodwill impairment loss is not recognized in timely manner and profit tends to be overstated due to managers' opportunistic manipulation after IFRS adoption (Carlin \& Finch, 2011; Wines, Dagwell, $\&$ Windsor, 2007). Second, it is mandatory to evaluate goodwill account in fair value. Unlike tangible assets, goodwill 
is recognized as an indefinite asset and impairment test should be performed every year, which eliminates sample selection bias. Third, goodwill accounting method changed dramatically from straight line amortization to impairment loss recognition after IFRS adoption. Due to such characteristics, we expect goodwill is a reasonable proxy for investigating the actual condition of fair value evaluation system after adopting IFRS.

Using a sample of firm-year observations from 2011 to 2012, 93 out of 283 firm-year observations recognized value of goodwill in 2009 or 2010 using K-GAAP goodwill standard and did not recognize impairment loss afterwards. The fact that these firms maintains goodwill value from 2009 or 2010 based on K-GAAP, even though goodwill could be easily impaired by economic environment, indicates such firms fair value system is weak at the time of introduction and after adopting IFRS. We separate the sample depending on whether they recognized historical goodwill value using K-GAAP or whether they recognized impairment loss of goodwill after IFRS adoption. We consider the former group to have a weak fair value evaluation system and latter to have a stronger one, and compare earnings quality between two groups under IFRS.

We follow Barth, Landsman, \& Lang (2008) and measure income smoothing, earnings management to meet-and-beat target, immediate loss recognition, book value of equity and goodwill from relative value relevance perspective. Results are as follows. First, firms with weak fair value system smooth income more frequently. Firms with weak fair value system have lower variance of net income change and variance of net income change to variance of operating cash flow change, which are measures for income smoothing. The difference between firms with weak or strong fair value system was significant at $1 \%$ level. Results indicate poor quality of fair value system is correlated with income smoothing. It is also consistent with prior literatures that lower net income change volatility and cash flow change to net income change volatility are related to higher income smoothing (Leuz, Nanda, \& Wysocki, 2003; Lang, Raedy, \& Wilson, 2006). Second, firms with weak fair value system experience small amount of positive profit and slight increase in net income compared to prior period more frequently. Based on the fact that profit close to zero or slight increase in net income are evidence of earnings management (DeGeorge, Patel, \& Zeckhauser, 1999; Burgstahler \& Dichev, 1997), result suggests management from weak fair value system could manage earnings through fair value evaluation in order to meet-or-beat target earnings. Third, firms with weak fair value system make less timely loss recognition. Firms with high earnings quality tend to immediately recognize loss based on prior studies. Therefore, we interpret firms with poor fair value system would have lowered earnings quality after IFRS adoption by delaying loss recognition. Lastly, book value of equity and goodwill has low relative value relevance for weak fair value systemic firms, while both book value of equity and goodwill have incremental value relevance for firms with strong fair value evaluation system. Based on the prior literature that earnings quality is positively related with explanatory power for stock price (Barth, Beaver, Landsman, 2001), we expect firms with poor fair value evaluation system manage earnings more frequently, which will eventually decrease the explanatory power of financial information for stock price.

The remainder of the paper is organized as follows. Section 2 discusses related studies and develop hypothesis. Section 3 describes research methodologies and samples. Section 4 provides empirical evidence and Section 5 concludes the paper.

\section{PRIOR LITERATURES AND HYPOTHESES DEVELOPMENT}

Recent research investigates relative value relevance of financial information after IFRS adoption. However, result is mixed, especially for how change in cost of equity book value or net income due to IFRS adoption affect relative value relevance. Hung and Subramanyam (2007) find that relative value relevance of financial information improved after adopting IFRS, especially for book value of equity, using German sample. On the other hand, Capkun, Jeny-Cazavan, Jeanjean, \& Weiss (2008) document that adjusted profit recognized by adopting IFRS has additional relative value relevance, while adjusted net income does not.

Mixed result is consistent using Korean sample. Choi et al. (2011) provide evidence that amount of adjusted profit recognized during switching to IFRS has relative value relevance, but amount of adjusted equity book value does not have relative value relevance. Choi (2013) find amount of adjusted equity book value due to IFRS adoption is negatively correlated with stock price, and adjusted profit amount does not have statistically significant association with stock price. 
There is much evidence on effect of IFRS adoption on book value of equity is indifferent from K-GAAP from relative value relevance perspective. We consider the fact effect of IFRS adoption on capital market could differ by firm characteristic (Daske, Hail, Leuz, \& Verdi, 2008; Christensen, Hail, \& Leuz, 2013), and expect IFRS adoption effect on earning quality could be different depending on firm characteristics and each firm's fair value evaluation system. If firms utilize IFRS fair value system as a method of income smoothing or meet-or-beat target earnings, firms' equity book value relative value relevance would be lower compared to K-GAAP. On the same note, if firms use fair value system under IFRS in order to reflect firms' economic substance, relative value relevance of equity book value would improve.

We thus expect that earnings management for income smoothing or meet-or-beat target earnings would be different by firm's fair value evaluation system, and whether such difference influence relative value relevance for stock price. We analyze the effect of firm's fair value evaluation system on earnings quality under IFRS and set a hypothesis as follow.

Hypothesis: There is a significant association between firm's fair value system and earnings quality under IFRS.

\section{RESEARCH METHODOLOGY}

\subsection{Measure of Firm's Fair Value System}

In order to examine firm's fair value system effect on earnings quality, we use goodwill accounting method as a proxy for fair value system. Our empirical analyses are based on 147 firms which recognized goodwill in 2011 or 2012. 49 firms out of 147 recognized a same amount of goodwill as 2009 and 2010 based on K-GAAP, and did not recognized any impairment loss under IFRS. Based on prior studies that firms use goodwill to manage earnings (Carlin \& Finch, 2011; Wines et al. 2007), we expect firms which continued to use goodwill value under K-GAAP and not recognized impairment loss to be firms with weak fair value evaluation system $(F V S=1)$. We consider firms that recognized impairment loss after adopting IFRS to be firms with strong fair value system $(F V S=0)$, and compare earnings quality of two groups under IFRS.

\subsection{Measure for Earnings Management}

We follow Barth et al. (2008) in measuring earnings quality, and use following four factors.

First, we use the variance of change in net income ( $\triangle E A R N V)$ to measure level of firms' income smoothing. Firms with large variance in net income change smooth income less (Leuz et al. 2003; Lang et al 2006), therefore it is reasonable to assume firms with small net income change variance is related with high income smoothing. Considering net income change could be caused by outside factors, we use residual ( $\triangle E A R N V$ ) from equation (1) to measure the net income change variance. We perform F-test to examine whether net income change variance is statistically significant depending on level of fair value system $(F V S)$.

\section{Equation (1)}

$$
\begin{aligned}
\triangle E A R N= & a_{0}+a_{1} S I Z E+a_{2} G R O W+a_{3} C S+a_{4} L E V+a_{5} L I A+a_{6} T U R N+a_{7} C F+a_{8} B I G 4 \\
& +a_{9} M R K T+\text { YearDummy }+\varepsilon
\end{aligned}
$$

where,

$$
\begin{array}{ll}
\triangle E A R N & =\text { change in net income; } \\
\triangle E A R N V & =\text { variance of change in net income, residual from equation (1); } \\
\text { SIZE } & =\text { natural log of total asset; } \\
\text { GROW } & =\text { sale growth; } \\
C S & =\text { percent change in common stock capital sourcing; } \\
L E V & =\text { leverage, measured by total liabilities divided by total assets; } \\
L I A & =\text { percent change in total leverage; } \\
T U R N & =\text { total sale divided by total asset; }
\end{array}
$$




$$
\begin{array}{ll}
C F & =\text { operating cash flow divided by total asset; } \\
B I G 4 & =1 \text { if auditor is one of Big } 4,0 \text { otherwise; } \\
M R K T & =1 \text { if listed in KOSDAQ, } 0 \text { otherwise. }
\end{array}
$$

Second, we measure the level of earnings management using the ratio of variance of the change in net income $(\triangle E A R N V)$ to the variance of the change in cash flows $(\triangle C F V)$. Firms which managed earnings would have lower net income change variance to cash flow change variance, thus $\triangle E A R N$ will have lower coefficient value than $\triangle C F$. In order to eliminate outside influence on $\triangle E A R N V$ and $\triangle C F V$, we use residual from equation (1) and (2).

\section{Equation (2)}

$$
\begin{aligned}
\triangle C F= & a_{0}+a_{1} S I Z E+a_{2} G R O W+a_{3} C S+a_{4} L E V+a_{5} L I A+a_{6} T U R N+a_{7} C F+a_{8} B I G 4 \\
& +a_{9} M R K T+\text { YearDummy }+\varepsilon
\end{aligned}
$$

where,

$$
\begin{aligned}
& \triangle C F=\text { change in operating cash flow; } \\
& \triangle C F V=\text { variance of the change in operating cash flow, residual from equation (2). }
\end{aligned}
$$

Third, we use the frequency of small positive net income to measure earnings management. Logit analysis is performed using equation (3). We use the ratio of current net income to market value of equity $(S P)$ is between $0 \%$ and $1 \%$ as dependent variable and level of fair value system $(F V S)$ as independent variable. Coefficient of $F V S$ will be positive if firms with weak fair value system have higher frequency of slightly positive income.

\section{Equation (3)}

$$
\begin{aligned}
S P= & a_{0}+a_{1} F V S+a_{2} S I Z E+a_{3} G R O W+a_{4} C S+a_{5} L E V+a_{6} L I A+a_{7} T U R N+a_{8} C F+a_{9} B I G 4 \\
& +a_{10} M R K T+\text { YearDummy }+\varepsilon
\end{aligned}
$$

where,

$S P=1$ if market value of equity to current net income is more than $0 \%$ and less than $1 \%, 0$ otherwise;

$F V S=1$ if firm has weak fair value system, 0 otherwise.

Fourth, we use the frequency of small increase in net income to measure earnings management. We perform logit regression using equation (4). If a firm has a weak fair value system and has a higher frequency of small increase in net income, coefficient for $F V S$ would have significantly positive value.

\section{Equation (4)}

$$
\begin{aligned}
S I= & a_{0}+a_{1} F V S+a_{2} S I Z E+a_{3} G R O W+a_{4} C S+a_{5} L E V+a_{6} L I A+a_{7} T U R N+a_{8} C F+a_{9} B I G 4 \\
& +a_{10} M R K T+\text { YearDummy }+\varepsilon
\end{aligned}
$$

where,

$S I=1$ if market value of equity to current net income increase compare to prior period is more than $0 \%$ and less than $1 \%, 0$ otherwise.

\subsection{Measure for Immediate Loss Recognition}

High earnings quality is correlated with timely recognition of loss according to prior studies. This study considers higher frequency of recognizing large amount of loss would be related to higher earning quality. If firms' current net loss is more than $10 \%$ of market value of asset, it has value of 1 and 0 otherwise. We expect coefficient of $F V S$ to be negative, if firms with weak fair value system do not recognize timely loss frequently. 


\section{Equation (5)}

$$
\begin{aligned}
L N E G= & a_{0}+a_{1} F V S+a_{2} S I Z E+a_{3} G R O W+a_{4} C S+a_{5} L E V+a_{6} L I A+a_{7} T U R N+a_{8} C F+a_{9} B I G 4 \\
& +a_{10} M R K T+\text { YearDummy }+\varepsilon
\end{aligned}
$$

where,

$L N E G=1$ if current net loss is more than $10 \%$ of market value of asset, 0 otherwise.

\subsection{Measure for Relative Value Relevance}

High quality of earnings reflects firms' economic substances more efficiently. In other words, it would also be have high relative value relevance with stock return and book value of equity. We follow fair value model from Ohlson (1995) and measure relative value relevance between stock price and financial information. Because reasonableness of the fair value evaluation would influence explanatory power of equity book value for stock price, we divide the sample by FVS and compare explanatory power of equity book value for stock price. We use the difference in coefficient of determination between equation (6) and (7), in order to measure relative value relevance of equity book value. If fair value system affects explanatory power of equity book value, we expect firms with weak fair value system to have insignificant explanatory of equity book value for stock price.

\section{Equation (6)}

$$
M V E=a_{0}+a_{1} B V E+a_{2} E A R N+a_{3} L O S S+\text { YearDummy }+\varepsilon
$$

\section{Equation (7)}

$$
M V E=a_{0}+a_{1} E A R N+a_{2} L O S S+\text { YearDummy }+\varepsilon
$$

where,

$$
\begin{aligned}
& M V E=\text { Market value at year end; } \\
& B V E=\text { Book value at year end; } \\
& E A R N=\text { Net income; } \\
& L O S S=1 \text { if firm experienced net loss, } 0 \text { otherwise }
\end{aligned}
$$

In order to measure relative value relevance of goodwill, we analyze equity book value after subtracting stock price and goodwill book value $(B V E-G W)$, net income $(E A R N)$ and book value of goodwill $(G W)$. Difference in adjusted coefficient of determinant between equation (8) and (9) is used to measure relative value relevance of goodwill. If fair value system were to influence explanatory power of goodwill for value, goodwill book value of firm with weak fair value evaluation system would have insignificant explanatory power for stock price.

\section{Equation (8)}

$$
M V E=a_{0}+a_{1}(B V E-G W)+a_{2} E A R N+a_{3} L O S S+a_{4} G W+\text { YearDummy }+\varepsilon
$$

Equation (9)

$$
M V E=a_{0}+a_{1}(B V E-G W)+a_{2} E A R N+a_{3} L O S S+\text { YearDummy }+\varepsilon
$$

where,

$B V E-G W=$ Book value of goodwill subtracted from book value of equity at year end; 
$G W \quad=$ Book value of goodwill at year end

To minimize possible firm specific effect caused by panel data characteristic, we use firm cluster effect.

\subsection{Sample Selection}

We use firms listed in KOSPI or KOSDAQ, and recognized goodwill in 2011 or 2012. We exclude (1) financial institutions and insurance companies, (2) firms that pre-adopted IFRS, (3) firms lacking financial statement under IFRS after 2010, and (4) firms lacking the necessary data to calculate control variables. This process yields a final sample of 283 firm-year observations from 147 samples.

\section{EMPIRICAL RESULTS}

\subsection{Descriptive Statistics}

Table 1 presents descriptive statistics for the variables used in this study. Firms with weak fair value system $(F V S=1)$ have high frequency of small positive profit $(S P)$ and small increase in net income to prior period (SI), and low frequency of recognizing large amount of loss $(L N E G)$. We interpret the result that weak fair value systemic firms increase earning in order to meet target earning and do not recognize loss in timely manner.

Table 1. Descriptive Statistics

\begin{tabular}{|c|c|c|c|c|c|c|}
\hline \multirow{2}{*}{ Independent Variables } & \multicolumn{3}{|c|}{ Weak Fair Value System $(F V S=1)$} & \multicolumn{3}{|c|}{ Strong Fair Value System $(F V S=0)$} \\
\hline & Mean & Median & Std. & Mean & Median & Std. \\
\hline$\triangle E A R N$ & -0.007 & -0.001 & 0.088 & -0.002 & -0.010 & 0.156 \\
\hline$\triangle C F$ & 0.011 & 0.004 & 0.079 & -0.001 & -0.003 & 0.109 \\
\hline$S P$ & 0.097 & 0.000 & 0.297 & 0.032 & 0.000 & 0.175 \\
\hline$S I$ & 0.129 & 0.000 & 0.337 & 0.047 & 0.000 & 0.213 \\
\hline$L N E G$ & 0.065 & 0.000 & 0.247 & 0.242 & 0.000 & 0.429 \\
\hline$M V E$ & 1.099 & 0.714 & 0.929 & 0.971 & 0.683 & 0.789 \\
\hline$B V E$ & 0.601 & 0.559 & 0.184 & 0.564 & 0.579 & 0.221 \\
\hline$E A R N$ & 0.031 & 0.036 & 0.089 & -0.013 & 0.019 & 0.122 \\
\hline$G W$ & 0.049 & 0.020 & 0.086 & 0.045 & 0.014 & 0.091 \\
\hline SIZE & 25.763 & 25.420 & 1.461 & 25.522 & 25.255 & 1.577 \\
\hline GROW & 0.092 & 0.063 & 0.205 & 0.078 & 0.060 & 0.371 \\
\hline$C S$ & 0.035 & 0.000 & 0.170 & 0.107 & 0.000 & 0.402 \\
\hline$L I A$ & 0.198 & 0.091 & 0.434 & 0.120 & 0.033 & 0.553 \\
\hline$L E V$ & 0.892 & 0.789 & 0.946 & 1.253 & 0.727 & 1.451 \\
\hline$T U R N$ & 0.886 & 0.752 & 0.544 & 0.925 & 0.790 & 0.623 \\
\hline$C F$ & 0.062 & 0.066 & 0.076 & 0.037 & 0.031 & 0.091 \\
\hline$B I G 4$ & 0.688 & 1.000 & 0.466 & 0.563 & 1.000 & 0.497 \\
\hline$M R K T$ & 0.527 & 1.000 & 0.502 & 0.584 & 1.000 & 0.494 \\
\hline \# of Obs. & \multicolumn{3}{|c|}{93} & \multicolumn{3}{|c|}{190} \\
\hline
\end{tabular}

Table 2 shows the results of Pearson correlation. The results show that the firms' fair value system (FVS) has significant association with frequency of small positive profit $(S P)$ and small increase in net income $(S I)$. It was also negatively related with frequency of recognizing large loss $(L N E G)$ at $1 \%$ significance level. These relationships represent the possibility of firms with weak fair value system reporting small positive profit or small increased net income more frequently, while recognizing large amount of loss less frequently compared to firms with strong fair value system.

Fair value system has positive and significant correlation with current net earnings and book value of goodwill, thus we expect firms with consistent goodwill value will experience higher net income and goodwill value. However, variables known to affect earnings management are not yet controlled. Therefore, to collect more accurate results, we perform multiple regression analysis in following section. 
Table 2. Pearson Correlation Matrix

\begin{tabular}{|c|c|c|c|c|c|c|c|c|c|}
\hline & $F V S$ & $\triangle E A R N$ & $\triangle C F$ & $S P$ & SI & LNEG & $M V E$ & $B V E$ & $E A R N$ \\
\hline$\triangle E A R N$ & $\begin{array}{c}-0.016 \\
(0.787)\end{array}$ & & & & & & & & \\
\hline$\triangle C F$ & $\begin{array}{c}0.054 \\
(0.362)\end{array}$ & $\begin{array}{c}-0.104 \\
(0.079)\end{array}$ & & & & & & & \\
\hline$S P$ & $\begin{array}{c}0.136 \\
(0.021)\end{array}$ & $\begin{array}{c}0.011 \\
(0.844)\end{array}$ & $\begin{array}{l}-0.047 \\
(0.423)\end{array}$ & & & & & & \\
\hline$S I$ & $\begin{array}{c}0.146 \\
(0.013)\end{array}$ & $\begin{array}{c}0.017 \\
(0.768)\end{array}$ & $\begin{array}{c}-0.028 \\
(0.628)\end{array}$ & $\begin{array}{c}0.053 \\
(0.371)\end{array}$ & & & & & \\
\hline$L N E G$ & $\begin{array}{l}-0.215 \\
(0.000)\end{array}$ & $\begin{array}{c}-0.202 \\
(0.000)\end{array}$ & $\begin{array}{c}-0.068 \\
(0.250)\end{array}$ & $\begin{array}{l}-0.112 \\
(0.059)\end{array}$ & $\begin{array}{l}-0.134 \\
(0.023)\end{array}$ & & & & \\
\hline$M V E$ & $\begin{array}{c}0.071 \\
(0.230)\end{array}$ & $\begin{array}{c}0.106 \\
(0.072)\end{array}$ & $\begin{array}{c}0.081 \\
(0.169)\end{array}$ & $\begin{array}{c}0.185 \\
(0.001)\end{array}$ & $\begin{array}{c}0.016 \\
(0.779)\end{array}$ & $\begin{array}{c}-0.234 \\
(0.000)\end{array}$ & & & \\
\hline$B V E$ & $\begin{array}{c}0.082 \\
(0.165)\end{array}$ & $\begin{array}{c}0.122 \\
(0.039)\end{array}$ & $\begin{array}{c}0.011 \\
(0.853)\end{array}$ & $\begin{array}{c}0.038 \\
(0.518)\end{array}$ & $\begin{array}{c}0.061 \\
(0.305)\end{array}$ & $\begin{array}{c}-0.330 \\
(0.000)\end{array}$ & $\begin{array}{c}0.473 \\
(0.000)\end{array}$ & & \\
\hline$E A R N$ & $\begin{array}{c}0.182 \\
(0.002)\end{array}$ & $\begin{array}{c}0.366 \\
(0.000)\end{array}$ & $\begin{array}{c}0.021 \\
(0.717)\end{array}$ & $\begin{array}{c}0.016 \\
(0.780)\end{array}$ & $\begin{array}{c}0.110 \\
(0.064)\end{array}$ & $\begin{array}{c}-0.726 \\
(0.000)\end{array}$ & $\begin{array}{c}0.211 \\
(0.000)\end{array}$ & $\begin{array}{c}0.300 \\
(0.000)\end{array}$ & \\
\hline$G W$ & $\begin{array}{c}0.018 \\
(0.761) \\
\end{array}$ & $\begin{array}{c}0.164 \\
(0.005) \\
\end{array}$ & $\begin{array}{c}-0.032 \\
(0.590) \\
\end{array}$ & $\begin{array}{c}0.174 \\
(0.003) \\
\end{array}$ & $\begin{array}{c}0.023 \\
(0.691) \\
\end{array}$ & $\begin{array}{c}0.064 \\
(0.279) \\
\end{array}$ & $\begin{array}{c}0.319 \\
(0.000) \\
\end{array}$ & $\begin{array}{c}0.205 \\
(0.000) \\
\end{array}$ & $\begin{array}{l}-0.157 \\
(0.008) \\
\end{array}$ \\
\hline
\end{tabular}

Note: Parentheses indicate P-value.

\subsection{Multiple Regressions Analysis}

Table 3 presents the results of main regression model, the effect of level of fair value system under IFRS on earnings quality. Followings are noteworthy: First, firms with weak fair value system smooth earnings more compared to firms with strong fair value system. Coefficients for dispersions of net income variance ( $\triangle E A R N V$ ) for weak fair value firms $(F V S=1)$ and strong fair value firms $(F V S=0)$ are 0.0087 and 0.0202 respectively. The difference between two firms is statistically significant at $1 \%$ level. Ratios for dispersions of net income variance change $(\triangle E A R N V)$ to dispersion of operating cash flow change $(\triangle C F V)$ between firms with different level of fair value system are statistically significant at $1 \%$ level (coefficient $=1.5980$ and 3.9073). These finds lend support our hypothesis that firms with weaker fair value system manage earnings more.

Table 3. Earnings Management Metrics

\begin{tabular}{|c|c|c|c|}
\hline Earning Management Metric & $\begin{array}{l}\text { Weak Fair Value System } \\
\qquad(F V S=1)\end{array}$ & $\begin{array}{l}\text { Strong Fair Value System } \\
(F V S=0)\end{array}$ & F-test (P-value) \\
\hline Variability of $\triangle E A R N V$ & 0.0087 & 0.0202 & $2.323(0.00)$ \\
\hline Variability of $\triangle E A R N V$ over $\triangle C F V$ & 1.5980 & 3.9073 & $6.054(0.00)$ \\
\hline
\end{tabular}

Second, firms with poor quality fair value system experience higher frequency of small positive profit or slight increase in net income. Coefficient values of FVS are given in Table 4 (1.464 and 1.092). We also find weak fair value systemic firms recognize large amount of loss less frequently, supported by significant and negative coefficient value of $L N E G$. Because small positive profit or small increase in net income is sign of earnings management, results suggest managers from weak fair value system firms use fair value evaluation as a way of meeting target earnings. 
Table 4. Management of Earnings Target

\begin{tabular}{|c|c|c|c|c|c|c|}
\hline \multirow{2}{*}{ Independent Variables } & \multicolumn{2}{|c|}{$S P$} & \multicolumn{2}{|c|}{ SI } & \multicolumn{2}{|c|}{$L N E G$} \\
\hline & Coef. & t-stat. & Coef. & t-stat. & Coef. & t-stat. \\
\hline Intercept & $-13.744^{* * *}$ & -2.85 & $-9.98^{* * *}$ & -2.41 & $12.661^{* *}$ & 2.45 \\
\hline$F V S$ & $1.464^{* * *}$ & 2.70 & $1.092^{* *}$ & 2.19 & $-1.168^{*}$ & -1.80 \\
\hline SIZE & $0.457^{* *}$ & 2.49 & $0.307^{* *}$ & 2.01 & $-0.615^{* * *}$ & -3.05 \\
\hline GROW & -1.314 & -0.96 & $1.552^{* * *}$ & 2.64 & $-4.690^{* * *}$ & -4.04 \\
\hline$C S$ & -0.911 & -1.01 & $-3.303^{* *}$ & -2.15 & -0.190 & -0.40 \\
\hline$L E V$ & -0.197 & -0.33 & 0.207 & 0.64 & -0.080 & -0.21 \\
\hline$L I A$ & -0.180 & -0.56 & $-0.523^{*}$ & -1.73 & $1.073^{* * *}$ & 3.76 \\
\hline TURN & -1.114 & -1.35 & $-1.270^{* *}$ & -2.11 & -0.510 & -1.35 \\
\hline$C F$ & -4.720 & -0.84 & $-7.209^{*}$ & -1.70 & -3.506 & -1.33 \\
\hline BIG4 & -0.825 & -1.21 & 0.519 & 0.95 & 0.505 & 1.09 \\
\hline$M R K T$ & 0.986 & 1.23 & 0.532 & 0.93 & 0.204 & 0.36 \\
\hline Cluster effect & \multicolumn{2}{|c|}{ Included } & \multicolumn{2}{|c|}{ Included } & \multicolumn{2}{|c|}{ Included } \\
\hline Year Dummy & \multicolumn{2}{|c|}{ Included } & \multicolumn{2}{|c|}{ Included } & \multicolumn{2}{|c|}{ Included } \\
\hline \# of Obs. & \multicolumn{2}{|c|}{283} & \multicolumn{2}{|c|}{283} & \multicolumn{2}{|c|}{283} \\
\hline
\end{tabular}

Note: $* * *, * * *$ Denotes significance at the $0.10,0.05$, and 0.01 levels, respectively, all two-tailed.

Third, we find no correlation between equity book value and goodwill book value for firms with weak fair value system. Results of Vuong's test (Vuong, 1989) are shown in Table 5. Panel A represents results for firms with weak fair value system, and explanatory power of equity book value is statistically insignificant (Vuong Z-statistics $=0.63$, $\mathrm{p}$-value $=0.52$ ). On the other hand, firms with strong fair value system have significant explanatory power of equity book value, shown in Panel B (Voung Z-statistics $=4.31$, $\mathrm{p}$-value $=0.00$ ).

Table 5. Management of Earnings Test (Vuong's test)

\begin{tabular}{|c|c|c|c|c|}
\hline \multicolumn{5}{|c|}{ Panel A. Weak fair value system $(F V S=1)$} \\
\hline \multirow{2}{*}{ Independent Variables } & \multicolumn{2}{|c|}{ MVE (Eq. 6) } & \multicolumn{2}{|c|}{ MVE (Eq. 7) } \\
\hline & Coef. & t-stat. & Coef. & t-stat. \\
\hline intercept & 0.201 & 0.63 & $0.510^{* * *}$ & 2.79 \\
\hline$B V E$ & 0.570 & 0.96 & & \\
\hline$E A R N$ & $9.994^{* * *}$ & -11.79 & $10.762^{* * *}$ & 3.57 \\
\hline LOSS & $-11.797^{* * *}$ & -3.21 & $-12.148^{* * *}$ & -3.32 \\
\hline Year Dummy & \multicolumn{2}{|c|}{ Included } & \multicolumn{2}{|c|}{ Included } \\
\hline Cluster effect & \multicolumn{2}{|c|}{ Included } & \multicolumn{2}{|c|}{ Included } \\
\hline Adj. $R^{2}$ & \multicolumn{2}{|c|}{0.272} & \multicolumn{2}{|c|}{0.270} \\
\hline BVE incremental (Vuong) & \multicolumn{4}{|c|}{$0.002(Z=0.63)$} \\
\hline \# of Obs. & \multicolumn{4}{|c|}{93} \\
\hline
\end{tabular}

\begin{tabular}{|c|c|c|c|c|}
\hline \multicolumn{5}{|c|}{ Panel B. Strong fair value system $(F V S=0)$} \\
\hline \multirow{2}{*}{ Independent Variables } & \multicolumn{2}{|c|}{ MVE (Eq. 6) } & \multicolumn{2}{|c|}{ MVE (Eq. 7) } \\
\hline & Coef. & t-stat. & Coef. & t-stat. \\
\hline intercept & -0.233 & -1.54 & $0.741^{* * *}$ & 7.04 \\
\hline$B V E$ & $1.883^{* * *}$ & 4.86 & & \\
\hline$E A R N$ & $2.824^{*}$ & 1.80 & $5.195^{* * *}$ & 3.80 \\
\hline LOSS & $-3.607^{* *}$ & 2.15 & $-5.716^{* * *}$ & -3.47 \\
\hline Year Dummy & \multicolumn{2}{|c|}{ Included } & \multicolumn{2}{|c|}{ Included } \\
\hline Cluster effect & \multicolumn{2}{|c|}{ Included } & \multicolumn{2}{|c|}{ Included } \\
\hline Adj. $R^{2}$ & \multicolumn{2}{|c|}{0.329} & \multicolumn{2}{|c|}{0.074} \\
\hline BVE incremental (Vuong) & \multicolumn{4}{|c|}{$0.255\left(\mathrm{Z}=4.31^{* * *}\right)$} \\
\hline \# of Obs. & \multicolumn{4}{|c|}{190} \\
\hline
\end{tabular}


Table 6 reports the relative value relevance of goodwill book value, depending on the level of fair value system from Vuong's test (Vuong, 1989). Coefficient value of goodwill book value $(G W)$ from firms with weak fair value system is statically insignificant (Voung Z-statistic $=1.13$, p-value $=0.25$ ), shown in Panel A. However, results in Panel B goodwill book value has significant relative value relevance in case of firms with strong fair value system (Voung Zstatistic $=2.17$, $\mathrm{p}$-value $=0.02$ ). It is interesting to notice the coefficient of $B V E-G W$, goodwill book value subtracted from equity book value, does not have a significant coefficient value. The result lends support for the usage of goodwill as a proxy for fair value evaluation system.

Table 6. Value Relevance of Goodwill (Vuong's test)

\begin{tabular}{|c|c|c|c|c|}
\hline \multicolumn{5}{|c|}{ Panel A. Weak fair value system $(F V S=1)$} \\
\hline \multirow{2}{*}{ Independent Variables } & \multicolumn{2}{|c|}{$M V E$ (Eq. 8) } & \multicolumn{2}{|c|}{ MVE (Eq. 9) } \\
\hline & Coef. & t-stat. & Coef. & t-stat. \\
\hline intercept & 0.215 & 0.70 & 0.562 & 1.54 \\
\hline$B V E-G W$ & 0.375 & 0.59 & -0.103 & -0.15 \\
\hline$E A R N$ & $10.268^{* * *}$ & 3.64 & $10.901^{* * *}$ & 3.46 \\
\hline LOSS & $-11.291^{* * *}$ & -3.41 & $-12.183^{* * *}$ & -3.29 \\
\hline$G W$ & 2.754 & 1.59 & & \\
\hline Year Dummy & \multicolumn{2}{|c|}{ Included } & \multicolumn{2}{|c|}{ Included } \\
\hline Cluster effect & \multicolumn{2}{|c|}{ Included } & \multicolumn{2}{|c|}{ Included } \\
\hline Adj. $R^{2}$ & \multicolumn{2}{|c|}{0.311} & \multicolumn{2}{|c|}{0.262} \\
\hline$G W$ incremental (Vuong) & \multicolumn{4}{|c|}{$0.049(Z=1.13)$} \\
\hline \# of Obs. & \multicolumn{4}{|c|}{93} \\
\hline
\end{tabular}

\begin{tabular}{|c|c|c|c|c|}
\hline \multicolumn{5}{|c|}{ Panel B. Strong fair value system $(F V S=0)$} \\
\hline \multirow{2}{*}{ Independent Variables } & \multicolumn{2}{|c|}{ MVE (Eq. 8) } & \multicolumn{2}{|c|}{ MVE (Eq. 9) } \\
\hline & Coef. & t-stat. & Coef. & t-stat. \\
\hline intercept & 4.137 & 3.95 & 0.154 & 0.76 \\
\hline$B V E-G W$ & $1.490^{* * *}$ & 4.55 & $1.265^{* * *}$ & 3.18 \\
\hline$E A R N$ & $3.734^{* * *}$ & 2.69 & $3.373^{* *}$ & 2.21 \\
\hline LOSS & $-4.177^{* * *}$ & -2.81 & $-4.225^{* *}$ & -2.54 \\
\hline$G W$ & $4.137^{* * *}$ & 3.95 & & \\
\hline Year Dummy & \multicolumn{2}{|l|}{ Included } & \multicolumn{2}{|l|}{ Included } \\
\hline Cluster effect & \multicolumn{2}{|l|}{ Included } & \multicolumn{2}{|l|}{ Included } \\
\hline Adj. $R^{2}$ & \multicolumn{2}{|l|}{0.394} & \multicolumn{2}{|l|}{0.176} \\
\hline$G W$ incremental (Vuong) & \multicolumn{4}{|c|}{$0.198^{* *}\left(Z=2.17^{* *}\right)$} \\
\hline \# of Obs. & \multicolumn{4}{|l|}{190} \\
\hline
\end{tabular}

\section{CONCLUSION}

In this paper, we examine how fair value evaluation system under IFRS influence earnings quality using Korean data sample. We use goodwill evaluation as a proxy for the level of fair value system and compare earnings quality of firms with consistent goodwill value and firms with decreased goodwill after IFRS adoption.

The findings of this study indicate firms with poor quality fair value system have higher frequency of income smoothing and earnings management in order to reach target earnings, compared to firms with strong fair value system. Weak fair value system firms also recognize large amount of loss less frequently, thus decreases the relative value relevance of equity book value. Results suggest expanded fair value system under IFRS could be used as a method of earnings management, which will lessen the explanatory power of financial information for stock price in return.

Contributions of the paper are as follows. Our study provides useful insight to the effect of fair value system under IFRS on earnings quality. Results illustrate that the efficiency of financial information disclosed by firms could variate, depending on the level of fair value after IFRS adoption. We also use various variables used as a proxy for earnings management, which increases the creditability of our results. 
Like many other studies, this study has a limitation. The sample of our study is limited to the firms that recognize goodwill, because we use goodwill to measure firms' fair value system. Despite the limitation, we consider goodwill accounting method under IFRS to be a reasonable proxy for opportunistic earnings management. Furthermore, the study shed light on importance of fair value evaluation. Considering the recent adoption of IFRS, results of this paper would be useful for information users and regulators.

\section{AUTHOR BIOGRAPHIES}

Chang Seop Rhee is an assistant professor at Sejong University in Korea (1st Author).

Eun Sil Choi received her Ph.D. from School of Business at Korea University in Korea (Corresponding Author).

Ji Yeon Rye is a Ph.D. student of School of Business at Korea University in Korea (Coauthor).

\section{REFERENCES}

Barth, M. E., Beaver, W. H. \& Landsman, W. R. (2001). The relevance of the value relevance literature for financial accounting standard setting: another view. Journal of Accounting and Economics, 31(1), 77-104.

Barth, M. E., Landsman, W. R. \& Lang, M. H. (2008). International accounting standards and accounting quality. Journal of Accounting Research, 46(3), 467-498.

Burgstahler, D. C. \& Dichev, I. D. (1997). Earnings management to avoid earnings decrease and losses. Journal of Accounting and Economics, 24, 99-126.

Capkun, V., Jeny-Cazavan, A., Jeanjean, T. \& Weiss, L. A. (2008). Earnings management and value relevance during the mandatory transition from local GAAPs to IFRS in Europe. Working paper, HEC Paris.

Carlin, M., \& Finch, N. (2011). Goodwill impairment testing under IFRS: A false impossible shore? Pacific Accounting Review, 23(3), 368-392.

Choi, J. H. (2013). The adoption of IFRS and value relevance of accounting information. Korean Accounting Review, 38(1), 391424.

Choi, S., Kim, I. \& Choi, K. (2011). The early adoption of K-IFRS and its effect on the quality of accounting information. Korean Accounting Review, 36(2), 1-31.

Choi, E. S., \& Rhee, C. S. (2015). The effect of chief executive officers turnover on international financial reporting standards reconciliation. The Journal of Applied Business Research, 31(5), 1851-1860.

Christensen, H. B., Hail, L. \& Leuz, C. (2013). Mandatory IFRS reporting and changes in enforcement. Journal of Accounting and Economics, 56, 147-177.

Daske. H., Hail, L., Leuz, C. \& Verdi, R. (2008). Mandatory IFRS reporting around the world: early evidence on the economic consequences. Journal of Accounting Research, 46(5), 1085-142.

DeGeorge, F., Patel, J. \& Zeckhauser, R. (1999). Earnings management to exceed thresholds. Journal of Business, 72, 1-33.

Hung, M. \& Suburamanyam, K. R. (2007). Financial statement effects of adopting international accounting standards: The case of Germany. Review of Accounting Studies, 12(4), 623-657.

Lang, M., Raedy, J. \& Wilson, W. (2006). Earnings management and cross listing: are reconciled earnings comparable to US Earnings? Journal of Accounting and Economics, 42, 255-83.

Leuz, C., Nanda, D. \& Wysocki, P. D. (2003). Earnings management and investor protection: International comparison. Journal of Financial Economics, 69, 505-527.

Ohlson. J. (1995). Earnings, book value, and dividends in security valuation. Contemporary Accounting Research, 11(2), 660687.

Rhee, C. S., Yoo, Y. K. \& Cha, S. M. (2016). The effect of IFRS adoption on likelihood of management earnings forecasts: Evidence in Korea. The Journal of Applied Business Research, 32(6), 1697-1706.

Vuong, Q. H. (1989). Likelihood ratio tests for model selection and non-nested hypotheses. Econometrica, 57, $307-333$.

Wines, G., Dagwell, R., \& Windsor, C. (2007). Implications of the IFRS goodwill accounting treatment. Managerial Auditing Journal, 22(9), 862-880. 